\title{
Plant growth-promoting rhizobacteria induced resistance in Jatropha curcas through phenyl propanoid metabolism against Rhizoctonia bataticola
}

\author{
S. Kumar ${ }^{1}$, M. Singh ${ }^{2}$ and Sushil Sharma ${ }^{3^{*}}$ \\ ${ }^{1}$ Department of Plant Pathology, College of Agriculture, Chaudhary Charan Singh Haryana Agricultural University, \\ Hisar - 125004 (Haryana), INDIA \\ ${ }^{2}$ Department of Plant Pathology, College of Agriculture, Chaudhary Charan Singh Haryana Agricultural University, \\ Hisar - 125004 (Haryana), INDIA \\ ${ }^{3}$ Chaudhary Charan Singh Haryana Agricultural University, Regional Research Station, Bawal - 123501 \\ (Haryana), INDIA \\ *Corresponding Author. E-mail: skvrrsbawal@rediffmail.com \\ Received: April 26, 2016; Revised received: September 25, 2016; Accepted: January 11, 2017
}

\begin{abstract}
The root rot disease in Jatropha curcas L. caused by Rhizoctonia. bataticola (Taub.) Butler has been recorded in causing 10-12 per cent mortality of 20-30 days old seedlings of Jatropha curcas in southern Haryana. The incidence of this disease has also been observed from other parts of Haryana too. Induction of systemic resistance in host plants through microbes and their bioactive metabolites are attaining popularity in modern agricultural practices. Studies on the plant growth-promoting rhizobacteria induced resistance in Jatropha curcas through phenyl propanoid metabolism against Rhizoctonia bataticola were undertaken at Chaudhary Charan Singh, Haryana Agricultural University, Regional Research Station, Bawal. Three plant growth-promoting rhizobacteria (PGPRs) viz., Pseudomonas maltophila, Pseudomonas fluorescens and Bacillus subtilis were evaluated for their potential to induce systemic resistance in Jatropha against root rot. The maximum increase of 97 per cent in total phenols, 120 per cent in peroxidase, 123 per cent in polyphenol oxidase, 101 per cent in phenylalanine ammonia lyase and 298 per cent in tyrosine ammonia lyase was detected in plants raised with Pseudomonas fluorescens + Rhizoctonia bataticola inoculation in Jatropha curcas at 10 days post inoculation against control except total phenols where it was maximum $(99 \%)$ at $30 \mathrm{DPI}$. There was slight or sharp decline in these parameters with age irrespective of inoculations. The pathogen challenged plants showed lower levels of total phenols and enzymes. The observations revealed that seed bacterization with Pseudomonas fluorescens results in accumulation of phenolics and battery of enzymes in response to pathogen infection and thereby induce resistance systemically.
\end{abstract}

Keywords: Jatropha curcas root rot, Phenol oxidizing enzymes, Phenol synthesizing enzymes, Rhizoctonia bataticola

\section{INTRODUCTION}

Physic nut (Jatropha curcas L.) locally known as 'Ratanjot' belongs to family Euphorbiaccae. Recently, the economic importance of Jatropha has increased because of the use of its oil as a fuel (diesel) substitute. For mitigating climate change by reducing emission of green house gases, meeting rural energy needs, protecting the environment and generating gainful employments. It is truly a multipurpose tree species fit for agroforestry and other afforestation program. Jatropha is fortunate in having only a few pest and diseases. The root rot disease caused by Rhizoctonia. bataticola (Taub.) Butler has been recorded in causing 10-12 per cent mortality of 20-30 days old seedlings of Jatropha at Chaudhary Charan Singh Haryana Agricultural University, Regional Research Station, Bawal (Sharma and Kumar, 2009). The incidence of this disease has also been observed from other parts of
Haryana too. Plant enzymes and phenols are involved in different reactions against plant pathogens. These include oxidizing enzymes such as peroxidase (POD) and polyphenol oxidase (PPO), synthesizing enzymes like phenylalanine ammonia lyase (PAL), tyrosine ammonia lyase (TAL). Such enzymes have been correlated with defense against pathogens in several plants (Liang et al., 2011 in cucumber and Mishra et al., 2014 in tea). Subsequent studies have shown the involvement of a variety of plant growth promoting rhizobacteria (PGPR) and other bio control agents in induced systemic resistance (ISR) in several crops against a wide spectrum of pathogens including fungi (Ghosh, 2015), however, no work has been reported on the ability of PGPRs to stimulate higher level of defense enzymes in Jatropha. Plant can be induced to develop enhanced resistance to pathogen infection by treatment with a variety of abiotic and biotic inducers including PGPRs. The objective of this research was to 
study the biochemical basis of root rot resistance in Jatropha in search of a biochemical marker. Such study will result in better understanding the mechanism of defense in these plants. Knowledge of this interaction will be helpful in development of new concepts for disease resistance in crop protection and may also contribute to better understanding of the factors determining the expression of resistant genes.

\section{MATERIALS AND METHODS}

The studies were undertaken at Chaudhary Charan Singh Haryana Agricultural University, Hisar situated $29^{\circ} .10$ latitude north and $75^{\circ} .46$ longitude east at an elevation of 215.2 meters above mean sea level. The average rainfall is $425 \mathrm{~mm}$ out of which 75 per cent is received from July to September. The soil is sandy loam, slightly alkaline, low in organic carbon and available nitrogen, medium in available phosphorus and high in available potash. The experiment was conducted in earthen pots having $5 \mathrm{~kg}$ sterilized soil. The biocontrol agents viz., Pseudomonas fluorescens, P. maltophilia and Bacillus subtilis were grown in nutrient broth (peptone $5 \mathrm{~g}$, yeast extract $2 \mathrm{~g}$, sodium chloride $5 \mathrm{~g}$, beef extract $1 \mathrm{~g}$, distilled water $1000 \mathrm{ml}$ ) and the pathogen ( $R$. bataticola) on PDA (potato infusion $200 \mathrm{~g}$, dextrose $20 \mathrm{~g}$, agar $20 \mathrm{~g}$, distilled water $1000 \mathrm{ml}$ ). For each treatment, the seeds were surface sterilized with 2 per cent sodium hypochlorite solution for half a minute and then washed 2-3 times with sterilized distilled water. The seeds were coated with slurry of mycelial mat of the pathogen. The required quantity of mycelial mat (15 g/ kg seed) was taken in a container and sufficient quantity of water was added to make it as a thin paste but not too watery. The seed was mixed thoroughly with paste for even distribution of the pathogen. Suitable sticker like carboxy methyl cellulose $(0.1 \%)$ was added for better adherence of pathogen to the seed. The seed was dried in shade before sowing (Kumar et al., 2011). In case of inoculation with PGPRs + pathogen, the seeds were treated first with bio-agents (dipping in suspension of $1 \times 10^{8} \mathrm{cfu} / \mathrm{ml}$ for half an hour) and air dried followed by coating with mycelial mat of pathogen and again air dried to ensure the infection. Spore suspension was prepared by using haemocytometer (Begum et al., 2003; Michel Shoresh et al., 2005). Cultures were centrifuged at 10,000 rpm for $10 \mathrm{~min}$. The pellets were thus obtained suspended in distilled water and the inoculum load was adjusted to $1 \times 10^{8} \mathrm{cfu} / \mathrm{ml}$ for PGPRs based on spectrophotometery. Bacillus gave 0.45 OD@ $610 \mathrm{~nm}$ and Pseudomonas gave 0.5 OD@610 nm at $1 \times 10^{8} \mathrm{cfu} / \mathrm{ml}$. The seeds coated with $R$. bataticola and three PGPRs individually served as control. After seed treatment, 10 seeds were sown in each pot with three replications. The pots were watered regularly. The Jatropha curcas plants were raised as per treatments viz., seed inoculation with $P$. maltophilia; seed inoculation with $P$. fluroscens; seed inoculation with B. subtilis; seed inoculation with $R$. bataticola (pathogen); co-seed inoculation with $P$. maltophilia $+R$. bataticola; co-seed inoculation with $P$. fluroscens $+R$. bataticola; co-seed inoculation with $B$. subtilis $+R$. bataticola and control (untreated). The root samples were collected from uninoculated (control) and inoculated plants at $10^{\text {th }}, 20^{\text {th }}, 30^{\text {th }}, 40^{\text {th }}$ and $50^{\text {th }}$ days of inoculation. The sample required for enzymatic studies were collected in plastic bags and deep frozen until used. Quantitative assay of total phenols, peroxidase (POD), polyphenol oxidase (PPO), phenylalanine ammonia lyase (PAL) and tyrosine ammonia lyase (TAL) was carried out by method of (Mahadevan and Sridhar, 1982). Statistical analysis of data was done for calculating standard deviation (George and Willium, 1957).

\section{RESULTS AND DISCUSSION}

Total phenols: The biochemical changes in plant-pathogen interactions are accompanied by rapid increase in phenolic compounds. The phenolic compounds in root tissue have been related with disease resistance in number of plant-parasite interaction (Vidhyasekran, 1997). Results evaluated in terms of phenol content revealed that seed inoculation with PGPRs differently stimulated phenol bio-synthesis in Jatropha plants (Table 1). Seed treatment with PGRPs + pathogen caused remarkable increase (76-97\%) in phenol level at early stage of sampling (10 days post inoculation) as compared to healthy plant. Each treatment showed slight increase in phenol level up to 30 DPI. However, after 30 DPI, all treatments revealed gradual decrease in phenol level. Infection with the pathogen also led to increase in phenol level. Inoculation resulted in an increase $(13 \%)$ in phenol level at the early stage of infection (10 DPI). However, this effect rapidly declined with the plant age and disappeared at 20 days post inoculation and so on. Seed treated plants with PGPRs, however, expressed moderate (17-24\%) increase in phenol content and this increase was more significant at 10 days post inoculation. Even at 30 days post inoculation, the PGPRs + Pathogens treated plants had 80 to 99 per cent higher phenol level over the control but after 50 days i.e. at the late stage of infection this effect somewhat declined. Still 65 to 88 per cent higher level could be noticed at this stage. Results clearly showed that Jatropha plant developed much higher phenol level when treated/infected. Among the treatments, maximum increase in phenol level was recorded for co-seed inoculation with Psendomonas fluorescens, the most effective treatment at all stage of sampling, and minimum increase was recorded at early stage for seed inoculation with Bacillus subtilis + Pathogen. These finding also revealed that there was little change with age in all treatments except pathogen treatment which showed sharply decline. Jatropha plants showed slight increase 
Table 1. Effect of seed inoculation with different PGPRs and/or inoculation with R. bataticola on total phenol content in Jatropha plants.

\begin{tabular}{|c|c|c|c|c|c|}
\hline \multirow{3}{*}{ Treatments } & \multicolumn{5}{|c|}{ Total phenol (mg catechol $\mathrm{g}^{-1}$ fresh weight of roots) } \\
\hline & \multicolumn{5}{|c|}{ Days post inoculation (DPI) } \\
\hline & 10 & 20 & 30 & 40 & $\mathbf{5 0}$ \\
\hline \multirow[t]{3}{*}{ Pseudomonas maltophila } & $1.82 *$ & 1.82 & 1.83 & 1.81 & 1.78 \\
\hline & $(18.95)^{* *}$ & $(17.41)$ & $(18.06)$ & $(17.53)$ & $(17.10)$ \\
\hline & \pm 0.04 & \pm 0.03 & \pm 0.06 & \pm 0.03 & \pm 0.02 \\
\hline \multirow[t]{3}{*}{ Pseudomonas fluorescens } & 1.90 & 1.89 & 1.92 & 1.90 & 1.84 \\
\hline & $(24.18)$ & $(21.94)$ & $(23.87)$ & $(23.37)$ & $(21.05)$ \\
\hline & \pm 0.01 & \pm 0.03 & \pm 0.02 & \pm 0.02 & \pm 0.05 \\
\hline \multirow[t]{3}{*}{ Bacillus subtilis } & 1.79 & 1.81 & 1.82 & 1.80 & 1.75 \\
\hline & $(16.99)$ & $(16.77)$ & $(17.41)$ & $(16.88)$ & $(15.13)$ \\
\hline & \pm 0.01 & \pm 0.07 & \pm 0.03 & \pm 0.02 & \pm 0.02 \\
\hline \multirow[t]{3}{*}{ Rhizoctonia bataticola } & 1.73 & 1.53 & 1.37 & 1.19 & 1.10 \\
\hline & $(13.07)$ & $(-12.90)$ & $(-11.61)$ & $(-22.72)$ & $(-27.63)$ \\
\hline & \pm 0.05 & \pm 0.04 & \pm 0.03 & \pm 0.07 & \pm 0.08 \\
\hline \multirow[t]{3}{*}{ P. maltophila $+R$. bataticola } & 2.84 & 2.93 & 2.93 & 2.89 & 2.81 \\
\hline & $(85.62)$ & $(89.03)$ & $(89.03)$ & $(87.66)$ & $(84.86)$ \\
\hline & \pm 0.01 & \pm 0.04 & \pm 0.13 & \pm 0.09 & \pm 0.04 \\
\hline \multirow[t]{3}{*}{ P. fluorescens $+R$. bataticola } & 3.01 & 3.06 & 3.08 & 2.93 & 2.86 \\
\hline & $(96.73)$ & $(97.41)$ & $(98.70)$ & $(90.25)$ & $(88.15)$ \\
\hline & \pm 0.11 & \pm 0.04 & \pm 0.07 & \pm 0.02 & \pm 0.06 \\
\hline \multirow[t]{3}{*}{ B. subtilis $+R$. bataticola } & 2.70 & 2.82 & 2.79 & 2.62 & 2.51 \\
\hline & $(76.47)$ & $(81.93)$ & $(80.00)$ & $(70.12)$ & $(65.13)$ \\
\hline & \pm 0.01 & \pm 0.02 & \pm 0.02 & \pm 0.05 & \pm 0.03 \\
\hline \multirow[t]{3}{*}{ Control } & 1.53 & 1.55 & 1.55 & 1.54 & 1.52 \\
\hline & $(--)$ & $(--)$ & $(--)$ & $(--)$ & $(--)$ \\
\hline & \pm 0.05 & \pm 0.05 & \pm 0.02 & \pm 0.02 & \pm 0.02 \\
\hline
\end{tabular}

*Each value is mean of three observations, ${ }^{* *}$ Values in parentheses are per cent increase over control, \pm indicates standard deviation, DPI $=$ Days post inoculation

in total phenol level from 10 to 30 DPI and at later stage, a slight decrease was observed in each treatment except the treatment in which plant were inoculated with pathogen alone where it showed sharp decrease. Sreedevi and Charithadevi (2012) observed increase in phenolic content in roots of plant raised from $P$. fluorescens treated seeds when inoculated with Macrophomina phaseolina ( $R$. soloni). On infection with $R$. soloni, total phenols increased but this increase was much more in resistant apple root stocks (Sharma, 2003). An increase in phenolic content was observed in $5^{\text {th }}$ day after challenge inoculation with $M$. phaseolina in chickpea roots (Kumar et al., 2007).

Peroxidase activity (POD): The oxidative enzymes, such as peroxidase (POD) are known to be associated with the browning of host tissues. They are also capable of oxidizing phenolics and related compounds, thus, increasing their toxicity (Kosuge, 1969). The peroxidase enzymes are reported to regulate protein synthesis and phenyl propanoid cycle in host. It is evident from Table 2 that the treated plants always had higher (5-120\%) levels of peroxidase activity than untreated plants upto 20 DPI. The maximum and minimum effects were recorded with $P$. fluorescens + pathogen and pathogen alone, respectively. These were found to be most and least effective treatments. Inoculation with pathogen resulted in nine per cent increase in enzyme activity quite early after inoculation but later it declined by $34.42 \%$ at the final stage of sampling. The co-seed treated plants responded to inoculation with much greater increase $(120 \%)$ in PO activity after 10 DPI, but at 50 days, these responses became less pronounced (102 \%). Results also revealed that PO activity significantly increased after bacterization with $P$. maltophila, $P$. fluorescens and B. subtilis as compared to the control at all stages of sampling. Peroxidase activity at 10 DPI was further stimulated and reached to its peak when Jatropha seeds were co-inoculated with PGPRs and $R$. bataticola. Peroxidase activity was several folds higher than polypenol oxidase in infected roots. These results are in agreement with the findings of Sharma (2003) who reported increased level of POD in resistant root stocks of apple. Mishra et al. (2014) recorded higher 
Table 2. Effect of seed inoculation with different PGPRs and /or inoculation with $R$. bataticola on peroxidase activity (PO) in Jatropha plants.

\begin{tabular}{|c|c|c|c|c|c|}
\hline \multirow{3}{*}{ Treatments } & \multicolumn{5}{|c|}{ Peroxidase activity (D OD $\mathrm{min}^{-1} \mathrm{~g}^{-1}$ fresh weight) } \\
\hline & \multicolumn{5}{|c|}{ Days post Inoculation (DPI) } \\
\hline & $\mathbf{1 0}$ & 20 & 30 & 40 & 50 \\
\hline \multirow[t]{3}{*}{ Pseudomonas maltophila } & $14.33 *$ & 14.21 & 14.08 & 13.83 & 13.67 \\
\hline & $(16.22)^{* *}$ & $(14.50)$ & $(13.00)$ & $(12.25)$ & $(12.04)$ \\
\hline & \pm 0.27 & \pm 0.75 & \pm 0.88 & \pm 0.81 & \pm 0.38 \\
\hline \multirow[t]{3}{*}{ Pseudomonas fluorescens } & 15.16 & 14.83 & 14.50 & 14.33 & 14.17 \\
\hline & $(27.00)$ & $(19.50)$ & $(16.37)$ & $(16.31)$ & $(16.14)$ \\
\hline & \pm 0.79 & \pm 0.46 & \pm 0.36 & \pm 0.03 & \pm 0.23 \\
\hline \multirow[t]{3}{*}{ Bacillus subtilis } & 14.17 & 14.00 & 13.8 .3 & 13.50 & 13.17 \\
\hline & $(14.92)$ & $(12.81)$ & $(10.99)$ & $(9.75)$ & $(7.95)$ \\
\hline & \pm 1.07 & \pm 0.88 & \pm 0.77 & \pm 0.46 & \pm 0.13 \\
\hline \multirow[t]{3}{*}{ Rhizoctonia bataticola } & 13.50 & 13.00 & 12.01 & 10.23 & 8.00 \\
\hline & $(9.48)$ & $(4.75)$ & $(-3.61)$ & $(-10.63)$ & $(-34.42)$ \\
\hline & \pm 0.19 & \pm 0.12 & \pm 0.78 & \pm 0.03 & \pm 0.81 \\
\hline \multirow[t]{3}{*}{ P. maltophila $+R$. butaticola } & 25.00 & 24.00 & 23.67 & 23.20 & 22.33 \\
\hline & $(102.75)$ & $(93.39)$ & $(89.96)$ & $(88.31)$ & $(82.21)$ \\
\hline & \pm 0.39 & \pm 0.84 & \pm 0.71 & \pm 0.51 & \pm 0.94 \\
\hline \multirow[t]{3}{*}{ P. fluorescens $+R$. bataticola } & 27.17 & 26.50 & 25.66 & 25.00 & 24.72 \\
\hline & $(120.35)$ & $(113.53)$ & $(105.93)$ & $(102.92)$ & $(102.62)$ \\
\hline & \pm 0.23 & \pm 0.53 & \pm 0.50 & \pm 0.50 & \pm 0.56 \\
\hline \multirow[t]{3}{*}{ B. subtilis $+R$. bataticola } & 24.50 & 24.17 & 24.00 & 22.33 & 21.10 \\
\hline & $(98.70)$ & $(94.76)$ & $(92.26)$ & $(81.25)$ & $(72.95)$ \\
\hline & \pm 0.42 & \pm 0.59 & \pm 0.63 & \pm 0.45 & \pm 0.94 \\
\hline \multirow[t]{3}{*}{ Control } & 12.33 & 12.41 & 12.46 & 12.32 & 12.20 \\
\hline & $(---)$ & $(---)$ & $(---)$ & $(---)$ & $(---)$ \\
\hline & \pm 0.52 & \pm 0.02 & \pm 0.90 & \pm 0.72 & \pm 0.37 \\
\hline
\end{tabular}

*Each value is mean of three observations, **Values in parentheses are per cent increase over control, \pm indicates standard deviation.

activity of POD in tea cuttings treated with $P$. fluorescens in presence of pathogen causing brown root rot and charcoal stump rot.

Polyphenol oxidase activity (PPO): Polyphenol oxidase (PPO) is a key enzyme of phenylpropanoid metabolism. Kenten (1956) found that rapid initial increase in the activity of PPO in plant tissue after infection results from the accumulation of latent phenolase or from solubilizing phenolase from cellular structure. An increase in polyphenol oxidase activity has been noted in infected tissues, and is believed to block the infection through its oxidation products (Mishra et al., 2014; Ghosh, 2015). Higher activity of PPO was correlated with resistance of host tissue to various pathogens. This could be due to the conversion of phenols by activity of this enzyme to fungitoxic compounds, quinones, which are more toxic to the pathogens than the phenolics (Kumar et al., 2007 and Ghosh, 2015 in chickpea and ginger plants infected with M. phaseolina and Pythium sp, respectively). Experimental results presented in Table 3 revealed that PPO activity followed the same trends as PO activity. PPO activity in Jatropha inoculated with PGPRs, increased significantly as compared to the control. This significant increase was maintained at all stage of sampling in bacterized Jatropha roots in absence of pathogen challenge. PGPRs treated plant showed 5586 per cent increase in PPO activity at 10 DPI. However, later, it became less obvious and was only 34-61 per cent higher over the control. Only pathogen treated plants showed a rapid increase in PPO activity at early stages of inoculation. However, in later stage it declined sharply from 38 to 5.26 per cent. The co-seed treated plants responded to inoculation with much greater increase in PPO activity i.e. 100-124 per cent at 10 DPI and it sequentially decreased as the time period increased. The plants treated with $P$. fluorescens $+R$. bataticola were found to be most effective, as they elicited the maximum increase in enzyme activity i.e. 123.81 and 86.84 per cent at 10 DPI and 50 DPI, respectively. Hence it was the reason that $P$. fluorescens was found to be effective against root rot of Jatropha caused by $R$. bataticola. It was also revealed from the results that PPO activity had a negative correlation with plant age.

Phenyalanine ammonia lyase (PAL): When microor- 
Table 3. Effect of seed inoculation with different PGPRs and /or inoculation with $R$. bataticola on polyphenol oxidase activity (PPO) in Jatropha plants.

\begin{tabular}{|c|c|c|c|c|c|}
\hline \multirow{3}{*}{ Treatments } & \multicolumn{5}{|c|}{ Polyphenol oxidase activity (D OD $\mathrm{min}^{-1} \mathrm{~g}^{-1}$ fresh weight) } \\
\hline & \multicolumn{5}{|c|}{ Days Post Inoculation (DPI) } \\
\hline & 10 & 20 & 30 & 40 & $\mathbf{5 0}$ \\
\hline \multirow[t]{3}{*}{ Pseudomonas maltophila } & $0.71^{*}$ & 0.70 & 0.68 & 0.65 & 0.59 \\
\hline & $(69.04)^{* *}$ & $(66.66)$ & $(65.59)$ & $(62.50)$ & $(55.26)$ \\
\hline & \pm 0.05 & \pm 0.05 & \pm 0.08 & \pm 0.03 & \pm 0.09 \\
\hline \multirow[t]{3}{*}{ Pseudomonas fluorescens } & 0.78 & 0.75 & 0.71 & 0.66 & 0.61 \\
\hline & $(85.71)$ & $(78.57)$ & $(73.17)$ & $(65.00)$ & $(60.52)$ \\
\hline & \pm 0.05 & \pm 0.04 & \pm 0.05 & \pm 0.09 & \pm 0.09 \\
\hline \multirow[t]{3}{*}{ Bacillus subtilis } & 0.65 & 0.61 & 0.58 & 0.55 & 0.51 \\
\hline & $(54.76)$ & $(45.23)$ & $(41.46)$ & $(37.50)$ & $(34.21)$ \\
\hline & \pm 0.12 & \pm 0.09 & \pm 0.09 & \pm 0.08 & \pm 0.12 \\
\hline \multirow[t]{3}{*}{ Rhizoctonia bataticola } & 0.58 & 0.51 & 0.46 & 0.41 & 0.36 \\
\hline & $(38.09)$ & $(21.42)$ & (12.19) & $(2.50)$ & $(-5.26)$ \\
\hline & \pm 0.12 & \pm 0.03 & \pm 0.06 & \pm 0.08 & \pm 0.07 \\
\hline P. maltophila + & 0.90 & 0.83 & 0.78 & 0.73 & 0.66 \\
\hline \multirow{2}{*}{ R. bataticola } & $(114.29)$ & $(97.61)$ & $(90.24)$ & $(82.50)$ & (73.68) \\
\hline & \pm 0.04 & \pm 0.06 & \pm 0.04 & \pm 0.07 & \pm 0.07 \\
\hline P. fluorescens + & 0.94 & 0.88 & 0.81 & 0.75 & 0.71 \\
\hline \multirow[t]{2}{*}{ R. bataticola } & $(123.81)$ & $(109.52)$ & $(97.56)$ & $(87.60)$ & $(86.84)$ \\
\hline & \pm 0.19 & \pm 0.08 & \pm 0.05 & \pm 0.03 & \pm 0.06 \\
\hline B. subtilis + & 0.84 & 0.81 & 0.76 & 0.70 & 0.64 \\
\hline \multirow[t]{2}{*}{ R. bataticola } & $(100.00)$ & $(92.86)$ & $(85.36)$ & $(75.00)$ & $(68.42)$ \\
\hline & \pm 0.09 & \pm 0.04 & \pm 0.13 & \pm 0.04 & \pm 0.07 \\
\hline \multirow[t]{3}{*}{ Control } & 0.42 & 0.42 & 0.41 & 0.40 & 0.38 \\
\hline & $(---)$ & $(---)$ & $(---)$ & $(\ldots \ldots)$ & $(\ldots \ldots)$ \\
\hline & \pm 0.05 & \pm 0.06 & \pm 0.08 & \pm 0.02 & \pm 0.07 \\
\hline
\end{tabular}

* Each value is mean of three observations, ${ }^{*}$ Values in parentheses are per cent increase over control, \pm indicates standard deviation.

ganisms invade plants, major physiological changes including induction of plant defense enzymes are activated. PAL and TAL are key enzymes in the phenylpropanoid pathway. PAL is responsible for the conversion of L-phenylalanine to trans-cinnamic acid. Tcinnamic acid serves as a precursor for the biosynthesis of coumarins, isoflavonoids and lignin. While, TAL is responsible for conversion of amino acid tyrosine to coumaric acid, which is the precursor of flavanoids, lignin and phenolic phenyl propane. These compounds play an important role in resistance mechanisms (Mahadevan and Sridhar, 1982). Change in PAL and TAL activities accompanying fungal, viral and bacterial infections in plants have been reported by several other workers (Sharma, 2003; Salari et al. 2004; Ghosh, 2015). PAL and TAL are the key enzymes for the biosynthesis of phytoalexins. Phytoalexins are antimicrobial compounds, which are synthesized de novo in response to the infection (Dixon and Harrison 1990). The pattern of phenylalanine ammonia lyase (PAL) activities in healthy and inoculated with PGPRs and/or pathogen has been depicted in Table 4. There was a significant increase in PAL activities at all plant stages in each treatment as compared to the control. The seed treatment to pathogen alone resulted in slightly increase in PAL activity i.e. nine per cent increase at 10 DPI over the control. However, seed treatment to PGPRs recorded greater increase in PAL activity. Pseudomonas maltophila, $P$. fluorescens and $B$. subtilis showed 26, 60 and 18 per cent increase, respectively at 10 DPI. In case of seed treatment with only PGPRs, PAL activity was lower than co-seed treatment with PGPRs + pathogen. But it was still higher than seed treatment with pathogen alone. Co-seed treatment viz., $P$. maltophila + pathogen, $P$. fluorescens + pathogen and B. subtilis + pathogen showed 38, 101 and 24 per cent increase over the control at 10 DPI. It is also vivid from the data that PAL activities declined as plant age increased in all the treatments. However, Pseudomonas fluorescens + pathogen treated plants showed higher PAL activities $(38.20 \pm 1.71 \mu \mathrm{M})$ at $50 \mathrm{DPI}$ than the control $(23.84 \pm$ $1.45 \mu \mathrm{M})$ at $10 \mathrm{DPI}$.

Tyrosine ammonia lyase (TAL): Alterations in the activity of TAL in healthy and inoculated roots of the 
Table 4. Changes in phenylalanine ammonia lyase activity (PAL) in Jatropha roots due to seed treatment with PGPRs and/or inoculation with $R$. bataticola.

\begin{tabular}{|c|c|c|c|c|c|}
\hline \multirow{3}{*}{ Treatment } & \multicolumn{5}{|c|}{$\begin{array}{c}\text { Phenylalanine ammonia lyase activity } \\
\left(\mathrm{m} \text { mol cinnamic acid } \mathrm{ml}^{-1} \text { enzyme extract } \mathrm{h}^{-1}\right)\end{array}$} \\
\hline & \multicolumn{5}{|c|}{ Days Post Inoculation (DPI) } \\
\hline & 10 & 20 & 30 & 40 & 50 \\
\hline \multirow[t]{3}{*}{ Pseudomonas maltophila } & $30.00^{*}$ & 29.02 & 28.13 & 26.20 & 23.50 \\
\hline & $(25.83)^{* *}$ & $(23.59)$ & $(22.51)$ & $(19.20)$ & (16.97) \\
\hline & \pm 0.45 & \pm 1.54 & \pm 1.99 & \pm 0.11 & \pm 0.34 \\
\hline \multirow[t]{3}{*}{ Pseudomonas fluorescens } & 38.12 & 36.04 & 34.41 & 32.10 & 29.00 \\
\hline & $(59.90)$ & $(53.49)$ & $(49.87)$ & $(46.04)$ & $(44.35)$ \\
\hline & \pm 2.08 & \pm 0.26 & \pm 0.90 & \pm 0.38 & \pm 1.62 \\
\hline \multirow[t]{3}{*}{ Bacillus subtilis } & 28.13 & 27.50 & 26.60 & 25.00 & 22.75 \\
\hline & $(17.99)$ & $(17.12)$ & $(15.85)$ & $(13.73)$ & $(13.24)$ \\
\hline & \pm 1.62 & \pm 1.60 & \pm 1.26 & \pm 0.16 & \pm 1.22 \\
\hline \multirow[t]{3}{*}{ Rhizoctonia bataticola } & 26.07 & 24.73 & 23.04 & 20.80 & 18.66 \\
\hline & $(9.35)$ & $(5.32)$ & $(0.34)$ & $(-5.36)$ & $(-7.11)$ \\
\hline & \pm 0.33 & \pm 1.92 & \pm 0.63 & \pm 0.20 & \pm 1.15 \\
\hline \multirow[t]{3}{*}{ P. maltophila $+R$. bataticola } & 32.95 & 32.40 & 31.60 & 30.00 & 27.12 \\
\hline & $(38.21)$ & $(37.99)$ & $(37.63)$ & $(36.48)$ & (34.99) \\
\hline & \pm 1.31 & \pm 1.05 & \pm 052 & \pm 1.82 & \pm 0.27 \\
\hline \multirow[t]{3}{*}{ P. fluorescens $+R$. bataticola } & 48.00 & 47.10 & 45.00 & 42.39 & 38.20 \\
\hline & $(101.34)$ & $(100.59)$ & $(95.99)$ & $(92.87)$ & $(90.14)$ \\
\hline & \pm 1.70 & \pm 0.72 & \pm 1.39 & \pm 1.16 & \pm 1.71 \\
\hline \multirow[t]{3}{*}{ B. subtilis $+R$. bataticola } & 29.46 & 29.02 & 28.04 & 26.52 & 23.95 \\
\hline & $(23.57)$ & $(23.59)$ & $(22.13)$ & $(20.65)$ & $(19.21)$ \\
\hline & \pm 0.33 & \pm 1.36 & \pm 0.95 & \pm 0.11 & \pm 1.04 \\
\hline \multirow[t]{3}{*}{ Control } & 23.84 & 23.48 & 22.96 & 21.98 & 20.09 \\
\hline & $(--)$ & $(--)$ & $(---)$ & $(--)$ & $(--)$ \\
\hline & \pm 1.45 & \pm 1.15 & \pm 1.98 & \pm 1.30 & \pm 1.09 \\
\hline
\end{tabular}

*Values are mean of three replications, **Figures in parentheses are per cent increase over control, \pm indicates standard deviation

Jatropha are shown in Table 5. The overall general trend was almost similar to that of PAL. An inoculated plant with $R$. bataticola showed twice increase in activity, immediately after inoculation upto 10 DPI and thereafter a decrease was recorded. After 50 DPI infected plant with $R$. bataticola showed least activity of TAL $(3.52 \pm 0.57 \mu \mathrm{M})$ while co-seed inoculation with $P$. fluorescens + pathogen showed highest TAL activities (approx. four times over the control). This value was $18.60 \pm 0.43 \mu \mathrm{M}$ at $10 \mathrm{DPI}$ and trend continued even upto 50 DPI. In seed treatment with only PGPRs, TAL activity was lower (10.3-13.3 $\mu \mathrm{M})$ than co-seed treatment with PGPRs + pathogen (15.3-18.6 $\mu \mathrm{M})$ over the control $(4.7 \mu \mathrm{M})$. However, this value was higher than seed treatment with pathogen alone. PGPRs seed treatment viz. $P$. maltophila, P. fluorescens and B. subtilis showed two to three fold increase over control at 10 DPI. A negative correlation was observed between activity of TAL enzyme and plant age. Early induction of PAL and TAL by PGPRs may have resulted in the activation of defense system, however, simultaneous pathogenic challenge further induce higher TAL level.
Sharma (2003), Joshi et al. (2004) and Liang et al. (2015) recorded similar observations Sharma (2003) reported rapid increase in TAL activity upto 25 days of inoculation in apple root stocks after challenge inoculation with Pythium ultimum. Activity of TAL enzyme increased with increase in disease intensity indicating thereby that enzyme play an important role in defense against Alternaria blight in clusterbean (Joshi et al., 2004). Liang et al. (2011) observed that levels of TAL activities in PGPR treated roots of cucumber was significantly higher as compared to control after 5 days post inoculation. The increased expression of PAL and TAL activities by PGPRs might play a vital role in protecting jatropha plants against invasion of $R$. bataticola.

\section{Conclusion}

It can be concluded from the present findings that seed bacterization with Pseudomonas fluorescens induce accumulation of phenolics and battery of enzymes in response to pathogen infection which could be involved not only in plant defense response but may also be associated with induced resistance. The higher levels of total phenols and high activity of enzymes 
Table 5. Change in tyrosine ammonia lyase activity (TAL) in Jatropha roots due to seed treatment with PGPRs and/or inoculation with $R$. bataticola.

\begin{tabular}{|c|c|c|c|c|c|}
\hline \multirow{3}{*}{ Treatments } & \multicolumn{5}{|c|}{ Tyrosine ammonia lyase activity (m mol coumaric acid $\mathrm{ml}^{-1}$ extract $\left.\mathrm{h}^{-1}\right)$} \\
\hline & \multicolumn{5}{|c|}{ Days Post Inoculation (DPI) } \\
\hline & 10 & 20 & 30 & 40 & 50 \\
\hline \multirow{3}{*}{ Pseudomonas maltophila } & $12.99 *$ & 12.44 & 11.03 & 10.09 & 8.76 \\
\hline & $(178.16)^{* *}$ & $(171.72)$ & $(154.15)$ & $(139.10)$ & $(113.65)$ \\
\hline & \pm 0.57 & \pm 0.44 & \pm 0.53 & \pm 0.25 & \pm 1.04 \\
\hline \multirow[t]{2}{*}{ Pseudomonas fluorescens } & 13.27 & 12.82 & 11.94 & 10.97 & 10.25 \\
\hline & $(184.30)$ & $(180.00)$ & $(174.40)$ & $(160.00)$ & $(150.12)$ \\
\hline \multirow{3}{*}{ Bacillus subtilis } & \pm 0.56 & \pm 0.82 & \pm 0.87 & \pm 0.99 & \pm 0.84 \\
\hline & 10.37 & 10.00 & 9.06 & 8.20 & 7.00 \\
\hline & $(122.05)$ & (118.34) & $(108.76)$ & $(94.31)$ & $(70.73)$ \\
\hline \multirow{4}{*}{ Rhizoctonia bataticola } & \pm 0.25 & \pm 0.90 & \pm 0.83 & \pm 0.39 & \pm 0.72 \\
\hline & 7.00 & 6.26 & 5.11 & 3.88 & 3.52 \\
\hline & (49.89) & $(36.38)$ & (17.74) & $(-8.06)$ & $(-14.15)$ \\
\hline & \pm 0.63 & \pm 0.35 & \pm 0.84 & \pm 0.58 & \pm 0.57 \\
\hline \multirow[t]{2}{*}{ P. maltophila + R. butaticola } & $\begin{array}{c}17.85 \\
(282.22)\end{array}$ & $\begin{array}{c}16.76 \\
(266.15)\end{array}$ & $\begin{array}{c}15.62 \\
(259.90)\end{array}$ & $\begin{array}{c}14.77 \\
(250.00)\end{array}$ & $\begin{array}{c}12.74 \\
(210.75)\end{array}$ \\
\hline & & & \pm 0.53 & & \pm 0.03 \\
\hline \multirow[t]{2}{*}{ P. fluorescens $+R$. bataticola } & $\begin{array}{c}18.60 \\
(298.28)\end{array}$ & $\begin{array}{c}17.89 \\
(290.72)\end{array}$ & $\begin{array}{c}16.71 \\
(285.10)\end{array}$ & $\begin{array}{c}15.70 \\
(272.00)\end{array}$ & $\begin{array}{c}14.36 \\
(250.15)\end{array}$ \\
\hline & & & \pm 0.57 & & \pm 0.87 \\
\hline \multirow[t]{2}{*}{ B. subtilis $+R$. bataticola } & $\begin{array}{c}15.33 \\
(228.26)\end{array}$ & $\begin{array}{c}14.66 \\
(220.12)\end{array}$ & $\begin{array}{c}13.68 \\
(215.50)\end{array}$ & $\begin{array}{c}12.84 \\
(204.20)\end{array}$ & $\begin{array}{c}12.23 \\
(198.22)\end{array}$ \\
\hline & & & \pm 0.05 & & \pm 0.17 \\
\hline Control & $4.67(---)$ & $4.58(---)$ & $4.34(---)$ & $4.22(---)$ & $4.10(---)$ \\
\hline
\end{tabular}

*Each value is mean of three observations, **Values in parentheses are per cent increase over control, \pm indicates standard deviation

were recorded at 10 days of inoculation in Pseudomonas fluorescens + Rhizoctonia bataticola inoculated plants. The values of per cent increase in total phenols peroxidase, polyphenol oxidase, phenylalanine ammonia lyase and tyrosine ammonia lyase were 97, 120, 123, 101 and 298, respectively. The pathogen alone challenged plants showed lower levels of these parameters. It could be speculated that enhanced expression patterns of phenols and enzymes by Pseudomonas fluorescens might account for its ability to provide effective protection for Jatropha curcas from root rot caused by soil borne fungal pathogen Rhizoctonia bataticola.

\section{REFERENCES}

Begum, M., Ravishankar, R.V. and Lokesh, J.V. (2003). Effect of plant growth promoting rhizobacteria on seed borne pathogens of plant growth promoting rhizobacteria on seed borne pathogens. Indian Phytopath. 56: 156-158.
Dixon, R.A. and Harrison, M.J. (1990). Activation structure and organization of genes involved in microbial defence in plants. Advance Gen., 8: 165-234

George, W.S. and Willium, G.C. (1957). Statistical methods ( $6^{\text {th }}$ ed.). Oxford and IBH Publishing Company. pp. 541573

Ghosh, R. (2015). Enzymatic responses of ginger plants to Pythium infection after SAR induction. J. Plant Pathol. Microb., 6: 283

Joshi U.N., Gupta P.P., Gupta, U. and Kumar, S. (2004). Biochemical factors in clusterbean that impact Alternaria blight resistance. J. Mycol. Pl. Pathol., 34: 581-583

Kenten, R. H. (1956). Latent phenolase in extracts of broadbean (Vicia faba L.) leaves. Biochem. J., 68: 244251

Kosuge, T. (1969). The role of phenolics in host response to infection. Ann. Rev. Phytopathol., 7: 195-222

Kumar, S., Sharma, S., Pathak, D.V. and Beniwal, J. (2011). Integrated management of Jatropha root rot caused by Rhizoctonia bataticola. J. Trop. Forest. Sci., 23: 35-41

Kumar, Vinod., Kumar, A., Verma, V.C., Gond, S.K., and 
Kharwar, R.N. (2007). Induction of defense enzymes in Pseudomonas. fluorescens treated chickpea roots against Macrophomina phaseolina. Indian Phytopath., 60: 289295

Liang, Jian-Gen., Tao, Rong-Xiang., Hao, Zhong-na., Wang,Lian-ping and Zhang, Xin. (2011). Induction of resistance in cucumber against seedling damping-off by plant growth-promoting rhizobacteria (PGPR) Bacillus megaterium strain L8. African J. Biotechnol., 10: 6920 6927

Mahadevan, A. and Sridhar R. (1982). Methods in Physiological Plant Pathology. II. Ed. Sivakami Publications, Madras, India.

Michel, Shoresh., Yedidia, Iris. and Chet Han. (2005) Involvement of Jasmonic acid/Ethylene signaling pathway in the systemic resistance induced in cucumber by Trichoderma asperellum T 203. Phytopathology, 95: 76-84

Mishra, A.K., Morang, P., Deka, M., Nishant Kumar, S. and Dileep Kumar, B.S. (2014). Plant growth-promoting rhizobacterial strain-mediated induced systemic resistance in tea (Camellia sinensis (L.) O. Kuntze) through defense-related enzymes against brown root rot and charcoal stump rot. Appl. Biochem. Biotechnol., 174: 506-521

Salari, Moammad., Panjekeh, Naser., Nasirpoor, Zahrah and Abkhoo, Javad. (2012). Changes in total phenol, total proptein and peroxidase activities in melon (Cucumis melo L.) cultivars inoculated with Rhizoctonia solani. African J. Microbio. Res., 37: 6629-6634

Sharma, I.M. (2003). Relationship between phenylpropanoid metabolism and resistance to Pythium ultimum Trow. in apple rootstock. J. Mycol. Pl. Pathol. 33: 114-115

Sharma, Sushil and Kumar, Krishan. (2009). Root rot of Jatropha curcas incited by Rhizoctonia bataticola in India. Indian Forester, 135: 433-434

Sreedevi, Basavaraju and Charithadevi, Mekala. (2012). Mechanism of biological control of root rot of groundnut caused by Macrophomina phaseolina. Indian Phytopath., 65: 360-365

Vidhyasekran, P. (1997). Fungal pathogenesis in plants and crop molecular biology and host defence mechanism. Marck Dekker, New York, USA. 553pp. 